\title{
DURABILITY PROPERTIES OF CONCRETE CONTAINING HIGH VOLUME MALAYSIAN FLY ASH
}

\author{
B. Balakrishnan ${ }^{1}$, A.S.M. Abdul Awal ${ }^{2}$ \\ ${ }^{1,2}$ UTM Construction Research Centre, Faculty of Civil Engineering, Universiti Teknologi Malaysia \\ 81310 UTM Skudai, Johor, Malaysia.
}

\begin{abstract}
Fly ash is a by-product of coal combustion in thermal power plants, and Malaysia produces over one million tons of fly ash annually. The fly ash from this process is used in concrete for many reasons and one of which is to improve the concrete properties. The present study was carried out to determine the effect of high volume fly ash on concrete durability when exposed to chloride, acid and sulphate solutions. Four types of concrete mixes were prepared that consist of 0, 40,50 and 60\% of fly ash by weight of cement. The durability performances of high volume fly ash concrete against physical and chemical attack revealed that concrete with high volume fly ash demonstrated lesser chloride ion penetration, lower weight and strength loss in acid solution and completely stayed intact in sulphate solution throughout the period of exposure.
\end{abstract}

Keywords: High volume fly ash, pozzolan, chloride, acid, sulphate, concrete durability.

\section{INTRODUCTION}

Fly ash is an inorganic, a non-combustible waste product of coal-burning power plants. As coal is burnt at high temperatures, carbon is burnt off and great amounts of the mineral impurities are carried away by the flue gas in the form of ash. The molten ash is rapidly cooled and solidifies as spherical, glassy particle. Fly ash is used for various reasons and one of it is to improve the concrete durability. The durability of concrete has been an issue for many construction jobs around the world which leads to high maintenance and repair costs [1]. Chemical attacks such as chloride, acid and sulphate are very detrimental to concrete and were found to be major causes behind these issues. However, the use of pozzolanic materials such as fly ash in the concrete has found to improve the durability of the concrete significantly [2].

Fly ash has been used for a long time in the concrete production; however usually the proportions is only limited to 15 to $25 \%$ [3]. The HVFA term was introduced in CANMET in the 1980s, where the cement was replaced by at least $50 \%$ of fly ash. The further development of the project was to reduce the $\mathrm{CO}_{2}$ from the production of clinker of cement, consumption of limestone, clay and at the same time to recycle the fly waste which is generated from the coal fired power plant [4]. The benefits of high volume fly ash concrete are many-folds: technological, ecological and economical.

Fly ash is abundantly available in Malaysia, since the use of pulverised coal firing remains one of the ways of generating electricity in the country. The generation of fly ash is increasing year by year in and it is estimated that 2 million tonnes of fly ash will be generated annually in Malaysia [5].
Considering the availability of fly ash, an attempt was made to study the effect of high volume fly ash on concrete durability exposed to chloride, acid and sulphate attack.

\section{MATERIALS AND TEST METHODS}

\subsection{Fly ash, Cement, Aggregates and Admixture}

\subsubsection{Fly ash}

In coal fired power plants, the fly ash particles are generally collected using electrostatic precipitator and stored in a silo. The fly ash used in this study was obtained from Tanjung Bin Power Plant, which is located at Pontian of Johor, southern state of Malaysia. The fly ash obtained was in a powder form and no further grinding or processing was carried out on the ash.

\subsubsection{Cement}

The cement used in this study was an Ordinary Portland Cement (OPC) manufactured according to ASTM C150. The physical properties and chemical composition of OPC are shown with that of the fly ash.

\subsubsection{Aggregate}

The aggregate used for the concrete mixtures consists of fine and coarse types. The fine aggregate used was a saturated surface dry river sand with fineness modulus of 2.9 , passing through sieve size of $4.75 \mathrm{~mm}$, specific gravity of 2.6 and water absorption of $0.70 \%$. Whereas the coarse aggregate was a crushed granite with $20 \mathrm{~mm}$ maximum size, specific gravity of 2.7 and water absorption of $0.5 \%$. 


\subsubsection{Admixture}

A high range water-reducing superplasticizer was used in the concrete preparation. A slump of $50 \mathrm{~mm}$ was targeted for $0 \%$ fly ash concrete and the admixture dosage was kept constant for all the mixes thereafter.

\subsection{Concrete Mixes}

Four types of concrete mixes were made; one with OPC alone as binder and the other three mixes with OPC was replaced by weight of 40,50 and $60 \%$ of fly ash. All the ingredients of the concrete mixes were kept constant beside the fly ash proportions, as shown in Table 1.

Table -1: Concrete Mix Proportions

\begin{tabular}{|l|l|l|l|l|}
\hline $\begin{array}{l}\text { Material } \\
\left.\text { (kg/m } \mathbf{m}^{3}\right)\end{array}$ & $\begin{array}{l}\mathbf{0 \%} \\
\text { fly ash } \\
\text { concrete }\end{array}$ & $\begin{array}{l}\mathbf{4 0 \%} \\
\text { fly ash } \\
\text { concrete }\end{array}$ & $\begin{array}{l}\mathbf{5 0 \%} \\
\text { fly ash } \\
\text { concrete }\end{array}$ & $\begin{array}{l}\mathbf{6 0 \%} \\
\text { fly ash } \\
\text { concrete }\end{array}$ \\
\hline OPC & 420 & 252 & 210 & 168 \\
\hline Fly ash & 0 & 168 & 210 & 252 \\
\hline $\begin{array}{l}\text { Fine } \\
\text { aggregate }\end{array}$ & 815 & 815 & 815 & 815 \\
\hline $\begin{array}{l}\text { Coarse } \\
\text { aggregate }\end{array}$ & 994 & 994 & 994 & 994 \\
\hline Water & 185 & 185 & 185 & 185 \\
\hline $\begin{array}{l}\text { Superplasti- } \\
\text { cizer }\left(1 / \mathrm{m}^{3}\right)\end{array}$ & 2.94 & 2.94 & 2.94 & 2.94 \\
\hline
\end{tabular}

\subsection{Measurement of Degree of Chemical Attack}

\subsubsection{Chloride Attack}

The test for measuring the chloride attack was carried out on concrete cylinders with $100 \mathrm{~mm} \times 200 \mathrm{~mm}$ dimensions. Four concrete mixes as per in the Table 1 , were cast and water cured for 28 days. At the end of 28 days, the specimens were taken out and placed in a $5 \%$ sodium chloride solution for a duration of 90 days. The samples were then tested at 7 , 28 and 90 days. Upon reaching this required maturity, the specimens were taken out from the sodium chloride solution and split into 2 parts. The exposed areas of the cylinders were then sprayed with $0.2 \mathrm{~N}$ silver nitrate solution. The areas that were penetrated by the chloride ions changed color due to reaction between silver nitrate and chloride. The depths of penetration were determined by measuring the depth of color change at the perimeter of the broken cylinder.

\subsubsection{Acid Attack}

The test for the measurement of acid attack was carried out on concrete cubes with $100 \mathrm{~mm}$ sides. Four concrete mixes were cast and water cured for 28 days. At the end of 28 days, the samples were taken out and placed in a $2 \%$ hydrochloric acid solution for a maximum duration of 1800 hours. The specimens were then tested at 200, 600, 1000 and 1800 hours intervals. The $\mathrm{pH}$ of the acid solution was controlled at 2 as due to leaching of $\mathrm{Ca}(\mathrm{OH})_{2}$ from the concrete, the $\mathrm{pH}$ of the acid increases over time. Upon reaching the required testing internal, the concrete specimens were taken out from the acid solution, weighted and placed back to the acid solution. At the end of 1800 hours, the strength losses of the concrete cubes were determined using compressive strength machine.

\subsubsection{Sulphate Attack}

The test for the measurement of sulphate attack was carried out on $100 \mathrm{~mm}$ concrete cubes. Four concrete mixes as per in the Table 1, were cast and water cured for 28 days. At the end of 28 days, the samples were taken out and placed in a $10 \%$ sodium sulphate solution with an alternating drying and wetting system. The specimens were then visually tested at 28,90 and at 550 days. At the end of the 550 days, the residual strength was determined using a compressive strength machine.

\section{RESULTS AND DISCUSSION}

\subsection{Physical and Chemical Properties of Fly Ash}

The scanning electron microscope imaging as can be seen in Figure 1 reveals that the majority of fly ash particles are glassy in appearance and spherical in shape. The fly ash fineness was very close to OPC; on 45 micron sieve the fly ash had a residue of $21.5 \%$ and OPC had a value of $17.1 \%$.

The chemical composition, as illustrated in Table 2, reveals that fly ash is moderately rich in silica content $(49.98 \%)$ as compared to that of OPC (18.11\%). The $\mathrm{CaO}$ content, however was very low i.e. about $5.9 \%$. The sum of silica, alumina and iron oxide is $80.61 \%$, that satisfies the requirement to be classified as Class $\mathrm{F}$ according to the standard specified in ASTM C618 [6]. The silica content gives the fly ash a large amount opportunity to react with the $\mathrm{Ca}(\mathrm{OH})_{2}$ that is expected from the cement hydrations.

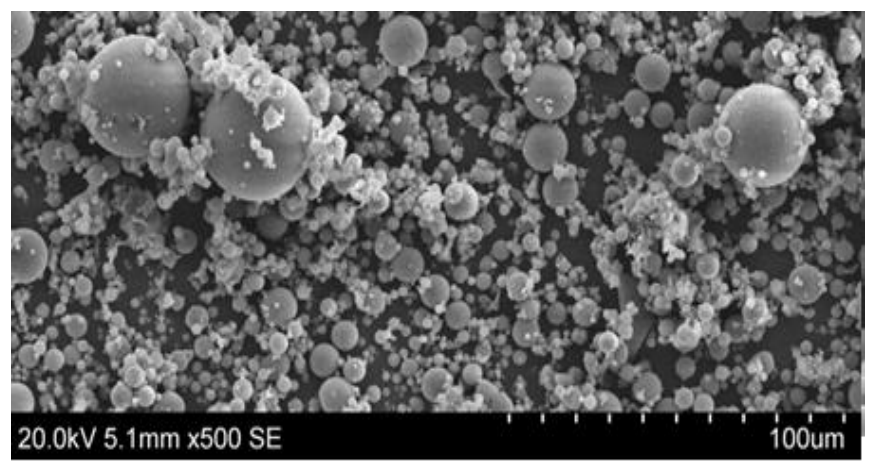

Fig-1: Morphology of Fly Ash 
Table -2: Physical Properties and Chemical Compositions of OPC and Fly Ash

\begin{tabular}{|l|l|l|}
\hline Test & OPC & Fly Ash \\
\hline \multicolumn{2}{|c|}{ Physical Properties } \\
\hline $\begin{array}{l}\text { Fineness-Blaine surface area } \\
\left(\mathrm{cm}^{2} / \mathrm{g}\right)\end{array}$ & 3400 & 3600 \\
\hline Specific Gravity & 3.12 & 2.23 \\
\hline Residue on 45 micron sieve (\%) & 17.1 & 21.5 \\
\hline \multicolumn{2}{|c|}{ Chemical Composition (\%) } \\
\hline Silicon dioxide $\left(\mathrm{SiO}_{2}\right)$ & 18.11 & 49.98 \\
\hline Aluminium oxide $\left(\mathrm{Al}_{2} \mathrm{O}_{3}\right)$ & 3.07 & 25.32 \\
\hline Ferric oxide $\left(\mathrm{Fe} \mathrm{O}_{3}\right)$ & 3.03 \\
\hline Calcium oxide $(\mathrm{CaO})$ & 65.88 & 5.31 \\
\hline Magnesium oxide $(\mathrm{MgO})$ & 1.87 & 5.92 \\
\hline Sulphur oxide $\left(\mathrm{Na}_{2} \mathrm{O}\right)$ & 0.47 & 0.51 \\
\hline Potassium Oxide $\left(\mathrm{K}_{2} \mathrm{O}\right)$ & 0.19 & 0.89 \\
\hline Loss on Ignition $(\mathrm{LOI})$ & 1.38 & 2.86 \\
\hline 28-Day strength activity index & - & $78 \%$ \\
\hline
\end{tabular}

\subsection{Workability and Strength of Concrete}

The results on workability and strength of concrete are summarized in Table 3. It has been found that the workability of the concrete increases with the additional of fly ash and it is suspected due to the spherical shape of fly ash, as can be seen in Figure 1. Among the four mixes, the highest compressive strength value was obtained for $0 \%$ fly ash concrete, while samples containing 40, 50 and $60 \%$ replacement made up 85,72 and $63 \%$ respectively of the control sample strength at 28 days.

Table-3: Workability and Compressive Strength of Concrete

\begin{tabular}{|l|l|l|}
\hline Type of Concrete & Slump (mm) & $\begin{array}{l}\text { 28-Day Compressive } \\
\text { Strength (MPa) }\end{array}$ \\
\hline 0\% Fly ash & 50 & 44.0 \\
\hline 40\% Fly ash & 130 & 37.4 \\
\hline $50 \%$ Fly ash & 160 & 31.7 \\
\hline 60\% Fly ash & 200 & 27.6 \\
\hline
\end{tabular}

\subsection{Resistance to Chloride Penetration}

Figure 2 reveals the penetration depth of the chloride ions after the exposure in sodium chloride solution. It was found that at 7 days of exposure, the penetration depth was highest for $0 \%$ fly ash concrete with a value of $7.05 \mathrm{~mm}$; and the difference was minimum with other fly ash mixes. However, at 28 and 90 days, the penetration depth for the $0 \%$ fly ash concrete has increased significantly to $13.10 \mathrm{~mm}$ and $19.20 \mathrm{~mm}$, but the high volume fly concrete chloride penetration depth was only about half and quarter of the value.. The lowest penetration depth was obtained for concrete with $60 \%$ fly ash with a penetration depth of $4.89 \mathrm{~mm}$ and $5.02 \mathrm{~mm}$ for 28 and 90 days respectively.

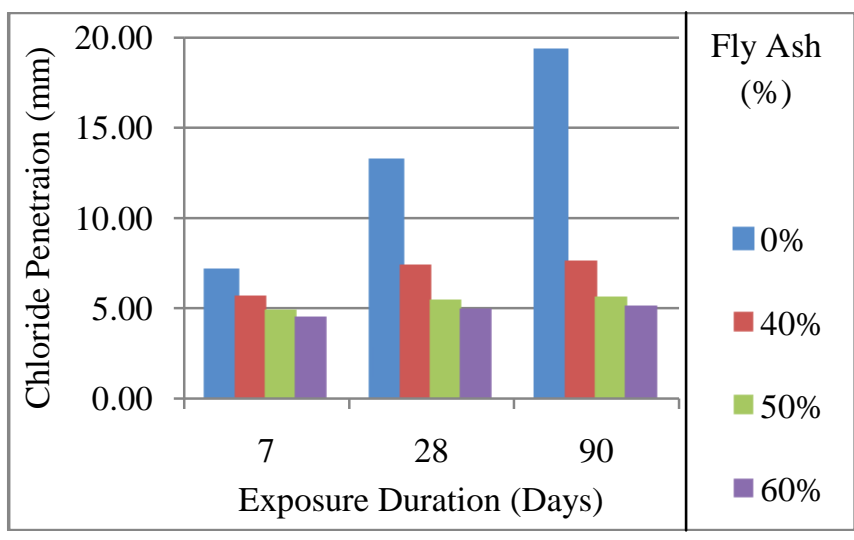

Fig -2: Chloride Penetration Depth

\subsection{Resistance to Acid Attack}

\subsubsection{Mass Change}

Figure 3 reveals that the weight loss of concrete increases when the samples are exposed to longer period in acid solutions. Up 600 hours, the $0 \%$ fly ash concrete had the lowest weight loss, however, the difference with the high volume fly ash concrete was little. At 1000 hours of exposure and onward, it was noticed that the $0 \%$ fly ash concrete suffered the highest weight loss. The weight loss of high volume fly ash concrete also started to stabilize after 1400 hours. As it can be observed in Figure 5, the higher weight loss of $0 \%$ fly ash concrete was mainly due to deterioration on the edges of the specimens, but the high volume fly ash concrete had only suffered minor surface erosion.

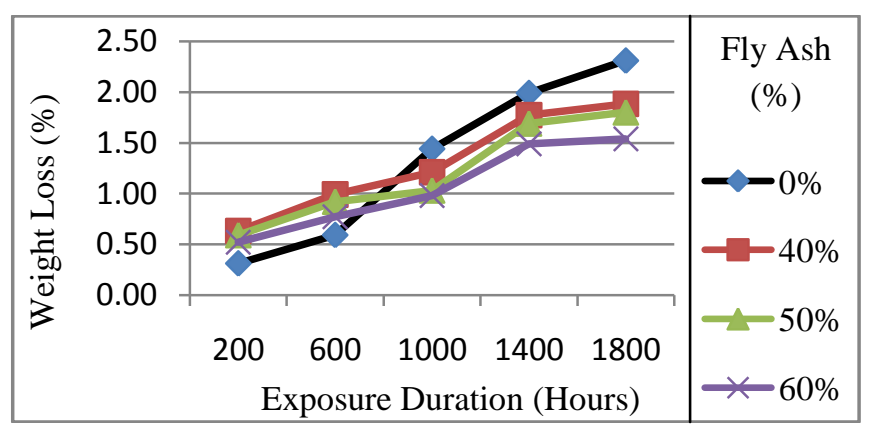

Fig -3: Weight Loss after Exposure to Acid

\subsubsection{Residual Compressive Strength}

All the concrete specimens suffered a strength loss after exposed to acid solution for 1800 hours. It can be observed in Figure 4 that the strength loss was highest for $0 \%$ fly ash concrete as compared to that in high volume fly ash concrete specimens for all levels of fly ash replacements. 


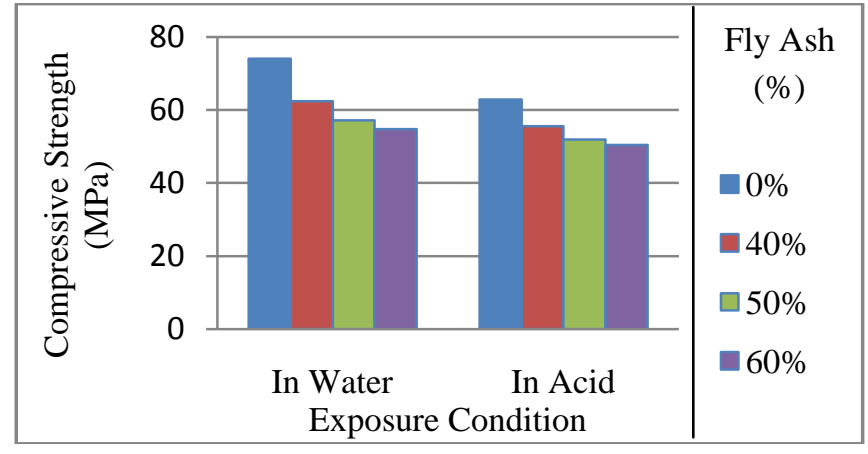

Fig -4: Strength Loss after Exposure to Acid for 1800 Hours

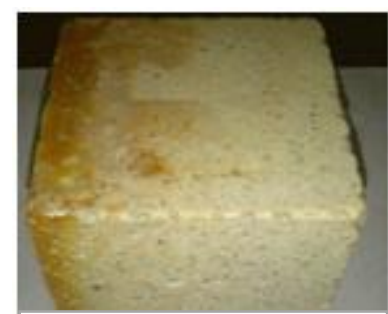

0\% Fly Ash Concrete

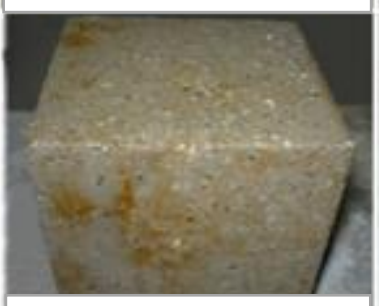

$50 \%$ Fly Ash Concrete

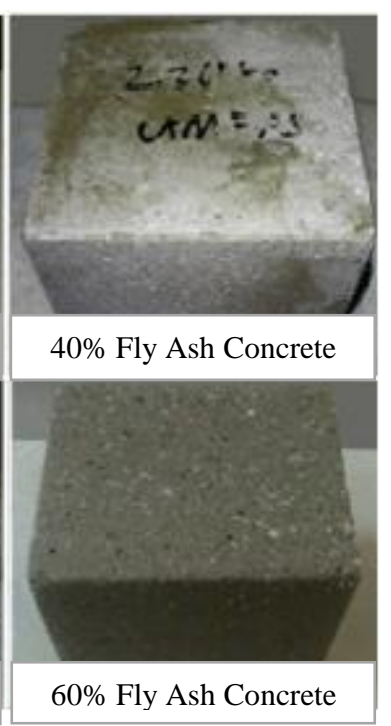

60\% Fly Ash Concrete
Fig -5: Concrete Specimen after Exposure to Acid for 1800 Hours

\subsection{Resistance to Sulphate Attack}

\subsubsection{Visual Observation and Residual Strength}

An inspection at the scheduled internal of 28 and 90 days did not reveal any visual changes to concrete specimens. However, at 550days of exposure, it can be observed in Figure 6 that the $0 \%$ fly ash concrete has seriously deformed, and it has also completely lost the compressive strength when tested. Meanwhile, the high volume fly ash concrete stayed intact without changes to the physical appearance. The investigation of the compressive strength also revealed that high volume fly ash concretes had continued strength gain even after 550 days of exposure in the sulphate solution. It is the pozzolanic behavior of the ash that might be responsible for maintaining the strength of high volume fly ash concrete over time.

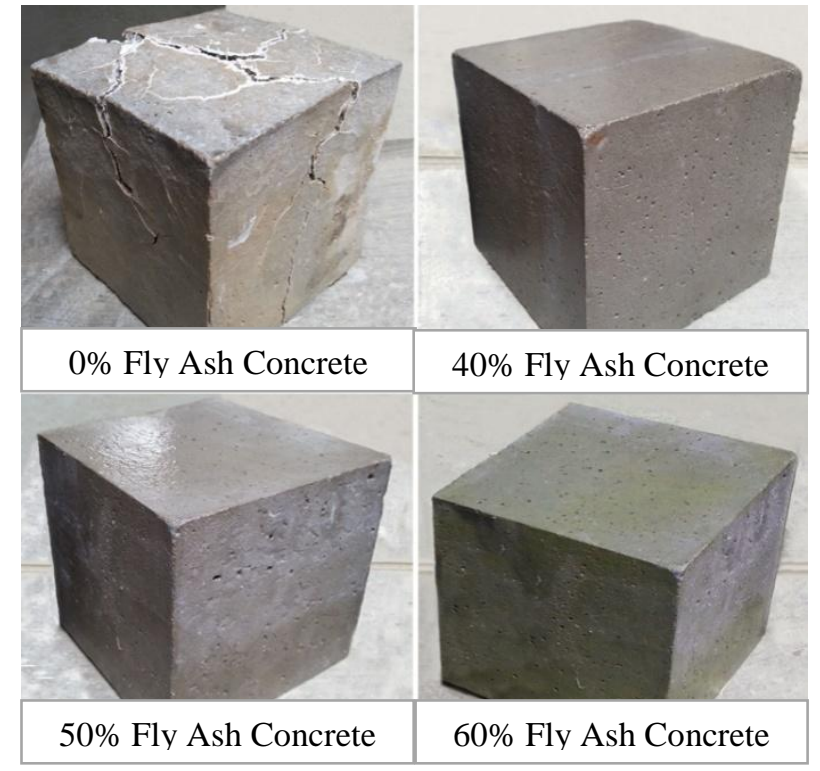

Fig -6: Concrete Specimen after Exposure to Sulphate Solution for 550 days

\section{CONCLUSIONS}

The results obtained and the observations made in this study suggest that concrete without any fly ash has suffered the most deterioration in all the three chemical solutions. The $0 \%$ fly ash concrete had the highest chloride penetration while high volume fly ash concrete had more than 50\% lower penetration in 90 days. Although the specimens with high volume fly ash had experienced some weight and strength loss, the values were much lower as compared to $0 \%$ fly ash concrete. The test on sulphate solution further showed the superiority of high volume fly ash concrete by staying intact in the solution for 550 days while the $0 \%$ fly ash concrete completely lost the strength. The increased resistance of the high volume fly ash concrete is suspected mainly due to consumption of the $\mathrm{Ca}(\mathrm{OH})_{2}$ which leads to reduced porosity and increased impermeability that prevented the migration of the detrimental chemical ions inside the concrete.

\section{ACKNOWLEDGEMENT}

The authors wish to acknowledge the technical support and co-operation received from Holcim Sdn Bhd Malaysia and Sto SEA Sdn Bhd in conducting the research work.

\section{REFERENCES}

[1] Chen, Z. J. (2006). Effect of Reinforcement Corrosion on the Serviceability of Reinforced Concrete Structures. Masters of Science in Engineering. University of Dundee, United Kingdom.

[2] Bouzoubaa, N., Zhang M. H. and Malhotra V.M. (2001). Mechanical Properties and Durability of Concrete Made With High-Volume Fly Ash Blended Cements Using a Coarse Fly Ash. Cement and Concrete Research. 31(3): 1393-1402. 
[3] Hopkins, D. S., Thomas, M. D. A., Oates, D. B., Girn, G. and Munro, R. (2001). York University Uses High-Volume Fly Ash Concrete for Green Building. ProceedingsCanadian Society for Civil Engineering. June 2011. Canada.

[4]Malhotra V. M. (1990). Durability of Concrete Incorporating High-Volume of Low-Calcium (ASTM Class F) Fly Ash. Cement and Concrete Composites. 12, 271-277.

[5] Rocktron International (2010). "International Greentech \& Eco Products Exhibition \& Conference Malaysia". www.rktron.com.my.

[6]ASTM C618 (2001). Standard Specification for Coal Fly Ash and Raw or Calcined Natural Pozzolan for Use as a Mineral Admixture for Concrete, Annual Book of ASTM Standards.

\section{BIOGRAPHIES}

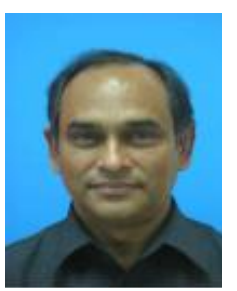

Dr. A.S.M. Abdul Awal is currently working as an international academic staff at Construction Research Centre, Faculty of Civil Engineering of the Universiti Teknologi Malaysia (UTM). Prior to joining UTM, he was a Professor in the Department of Farm Structure and Environmental Engineering, Bangladesh Agricultural University at Mymensingh. Professor Abdul Awal has over thirty years of teaching and research experience in the area of cement and concrete technology. $\mathrm{He}$ is the pioneer researcher in utilizing palm oil fuel ash (POFA) in producing high performance concrete, and in recent past he has introduced the concept of high volume POFA in green concrete construction. Apart from teaching and research, he is also well known for his interest and commitment to collaborate $\mathrm{R} \& \mathrm{D}$ activities for the betterment of local and global community.

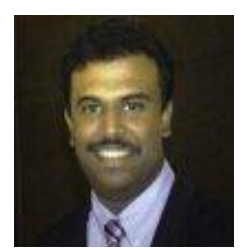

Balamohan Balakrishnan has received his Bachelor degree in Civil Engineering from Universiti Sains Malaysia (USM) in 2004. He is currently doing Master of Engineering in Structure and Materials at the Universiti Teknologi Malaysia (UTM). Since early this year he is also working as a Technical and Quality Manager with Sto SEA in Malaysia. His research interest includes high volume fly ash concrete. 